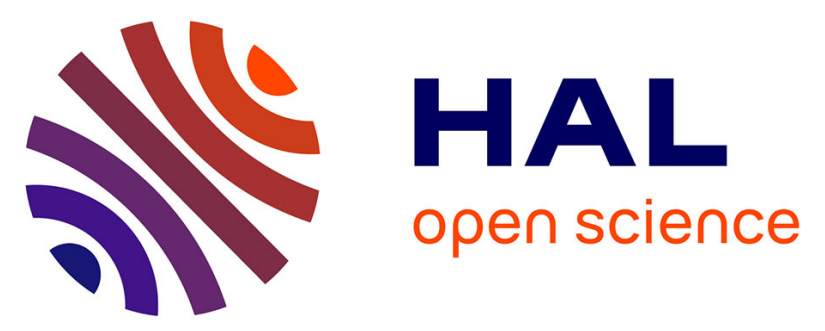

\title{
Anatomical and chemical analyses on wooden artifacts from a Samnite sanctuary in Hirpinia (Southern Italy)
}

Manuela Capano, Olivia Pignatelli, Chiara Capretti, Simona Lazzeri, Benedetto Pizzo, Fabio Marzaioli, Nicoletta Martinelli, Ida Gennarelli, Stefania Gigli, Filippo Terrasi, et al.

\section{To cite this version:}

Manuela Capano, Olivia Pignatelli, Chiara Capretti, Simona Lazzeri, Benedetto Pizzo, et al.. Anatomical and chemical analyses on wooden artifacts from a Samnite sanctuary in Hirpinia (Southern Italy). Journal of Archaeological Science, 2015, 57, pp.370 - 379. 10.1016/j.jas.2015.03.002 . hal-01684160

\section{HAL Id: hal-01684160 https://hal.science/hal-01684160}

Submitted on 29 Apr 2019

HAL is a multi-disciplinary open access archive for the deposit and dissemination of scientific research documents, whether they are published or not. The documents may come from teaching and research institutions in France or abroad, or from public or private research centers.
L'archive ouverte pluridisciplinaire $\mathbf{H A L}$, est destinée au dépôt et à la diffusion de documents scientifiques de niveau recherche, publiés ou non, émanant des établissements d'enseignement et de recherche français ou étrangers, des laboratoires publics ou privés. 


\title{
Anatomical and chemical analyses on wooden artifacts from a Samnite sanctuary in Hirpinia (Southern Italy)
}

\author{
Manuela Capano a, *, Olivia Pignatelli ${ }^{\text {b }}$, Chiara Capretti ${ }^{\mathrm{c}}$, Simona Lazzeri ${ }^{\mathrm{c}}$, \\ Benedetto Pizzo c, Fabio Marzaioli ${ }^{\text {d }}$, Nicoletta Martinelli b, Ida Gennarelli e, \\ Stefania Gigli ${ }^{\text {f }}$, Filippo Terrasi ${ }^{\mathrm{d}}$, Nicola Macchioni ${ }^{\mathrm{c}}$ \\ a Seconda Università degli Studi di Napoli - CIRCE (Centre for Isotopic Research on Cultural and Environmental Heritage), San Nicola la Strada, CE, Italy \\ ${ }^{\mathrm{b}}$ Dendrodata s.a.s., Verona, Italy \\ ${ }^{\mathrm{c}}$ CNR-IVALSA (Istituto per la Valorizzazione del Legno e delle Specie Arboree), Sesto Fiorentino, FI, Italy \\ ${ }^{\mathrm{d}}$ CIRCE - Dipartimento di Matematica e Fisica, Seconda Università degli Studi di Napoli, Caserta, Italy \\ e Soprintendenza Archeologica di Salerno, Avellino, Benevento and Caserta, Salerno, Italy \\ ${ }^{\mathrm{f}}$ Dipartimento di Lettere e Beni Culturali, Seconda Università degli Studi di Napoli, Santa Maria Capua Vetere, CE, Italy
}

\section{A R T I C L E I N F O}

\section{Article history:}

Received 31 March 2014

Received in revised form

16 February 2015

Accepted 2 March 2015

Available online 10 March 2015

In memoriam of Alfonso de Concilio

\section{Keywords:}

Wooden artifacts

Optical microscope

SEM

FTIR-ATR spectroscopy

$\mathrm{pH}$ measurement

Ash content

\begin{abstract}
A B S T R A C T
Objects of this study are the wooden artifacts discovered in the archaeological excavation of Mephitis goddess sanctuary in the Ansanto Valley (Rocca San Felice - AV, Southern Italy). At the moment of discovery, in the mid of last century, woods were waterlogged and mineralized, and they were restored to allow their preservation. Purpose of this work was the wood identification, in order to gain information on some technological aspects, and the analysis of wood preservation state.

Wood species were identified by means of magnifiers or optical and scanning electron microscopes, while the state of preservation was studied through microscopy and chemical analyses (FTIR-ATR, ash content and $\mathrm{pH}$ measurement). Four different taxa have been identified with certainty among all the findings: Quercus sp., Fagus sylvatica L., Rosaceae, Populus/Salix. It was not possible to identify the wood of all the findings, because some sampled fragments were too small or because of the deformation of wood tissues. The state of preservation showed a great variability over the analyzed findings. A general damage degree was observed, sometimes also macroscopically visible. The polarized light microscope and FTIRATR spectroscopy demonstrated the absence of cellulose in the analyzed samples. The wood cell wall was not detectable by means of SEM because it is completely covered by restoration material. Because of the lack of visibility, it was impossible to identify the type of biological damage occurred to the wood.
\end{abstract}

(C) 2015 Elsevier Ltd. All rights reserved.

\section{Introduction}

Around the half of the 1st millennium BC, goddess Mephitis was venerated in Hirpinia, in a sanctuary in the Ansanto Valley (in the municipality of Rocca San Felice, near Avellino, in the Campania region - Southern Italy), by Hirpini population, one of the four Samnite groups. Samnite economy was essentially tied to agriculture (cereals, viticulture, cultures of fruit trees and vegetables), timber sales and pastoralism; they plundered the neighboring

\footnotetext{
* Corresponding author. Present address: CEREGE, Aix-Marseille University, CNRS, IRD, Collège de France, Technopôle de l'Arbois, BP 80, F-13545 Aix-en-Provence, France. Tel.: +33 442507414

E-mail addresses: capano@cerege.fr, capanomanuela@tiscali.it (M. Capano).
}

territories, as well as they were mercenaries (practice testified by the belts and the weapons in male graves), but the wealth introduced by these activities was small and of short duration (Tagliamonte, 2005).

Some wooden objects were discovered in this sanctuary (Onorato, 1960). Their discovery has a great importance because of the rare finding of archaeological wood in Southern Italy, but, in this case, the importance is increased by the great historical-artistic and religious value of some of these objects. They are in particular wooden carvings sacred to the goddess.

The necessity to ensure the preservation over time to these objects and the possibility to increase the knowledge about Hirpini population were the main motivation driving this work. The wood species and the state of preservation of the findings were analyzed. The knowledge of wood species provides important information 
about the woodworking technology or the provenience of the wood (Corona, 2002; Macchioni and Lazzeri, 2008). It is well known that different species of wood have different characteristics and properties, depending on wood anatomy. Also prehistoric men well knew the properties of different types of wood and selected them in relation to the more appropriate wood characteristics for the intended purpose (Acanfora, 1970; Stotzer et al., 1976; Perini, 1988; McIntosh, 2009; Hodges, 2009). Sometime other reasons, not tied to wood characteristics, underlie the human choice of a wood species, such as the availability in the site or the religious worship.

Archaeological wood, in whatever way has been preserved, is often affected by deterioration. Microorganisms are one of the main causes of damage: they are mainly bacteria and fungi, deteriorating mostly cellulose, but also lignin. The kind of biological damage is usually investigated through the analysis of wood cell wall (Blanchette et al., 1991; Blanchette, 2000; Relini and Faimali, 2003; Caneva et al., 2007; Capretti et al., 2008; Čufar et al., 2008): in particular the use of different microscopes, like light microscope equipped with polarized mode and SEM (Scanning Electron Microscope), allow to highlight the aspect of degraded cells and what layer of the wall is attacked (Macchioni et al., 2013). Soft rot fungi and erosion bacteria cause often holes and strong deformations mostly into the secondary wall because they feed on cellulose: the consequence of this phenomena is the loss of birefringence observed in degraded wood (Čufar et al., 2014); when the decay is at a very advanced level, the holes join together and the wall becomes completely deformed (Pizzo et al., 2013a). The extent of the attack by biodeteriogenes and its consequence on the residual chemical composition of objects is usually evaluated by means of conventional (wet) analyses (Pizzo et al., 2010, 2013b). Yet, those analyses usually require a large amount of material, which is not always available in archaeological contexts. However, also spectroscopic measurements have shown to give reliable insights about the quantitative chemical composition of archaeological wood (Pizzo et al., 2013c). In general, the knowledge of the kind and of the level of deterioration allows the choice of the best conservative process for the objects.

In this study wood anatomy analysis (by means of magnifiers, stereoscope, optic microscopes and SEM) was useful for the wood species identification and the preservation state evaluation; chemical analyses (i.e. $\mathrm{pH}$ and ash content measurements and FTIRATR spectroscopy) were performed in order to analyze the current state of preservation of the restored findings respect to "nonrestored" or "differently restored" ones. This is important for determining the correct conservation conditions to which the findings should be subjected and for the decision about new consolidation work on the damaged wooden findings.

\section{Study area}

The Ansanto Valley is an area of calcareous formation (Sinno, 1969; Capano et al., 2013), crossed by a small river (Ansanto River) and a rivulet. It is characterized by gas exhalation phenomena (mainly $\mathrm{CO}_{2}, \mathrm{~N}_{2}$ and $\mathrm{H}_{2} \mathrm{~S}$; Chiodini et al., 2010): the gases arise from the subsurface and they diffuse in the atmosphere through cracks in the soil and small lakes with boiling mud (Manzi, 1997).

In the second half of the 1st millennium BC a sanctuary sacred to goddess Mephitis was present in the area. During Samnite period (6th to 4th century BC) the sanctuary was probably an enclosed sacred area of the forest (Rainini, 2003, 2008) and the sacrifice and offering rites took place near the biggest lake or the Ansanto River (characterized by strong gas emissions too). During the last centuries many landslides occurred because of the deforestation and the rock erosion, caused by the acid ground (Ortolani and Pagliuca, 2008; Gambino, 1991). The landslide has restricted the river bed, forcing the water to erode the right bank. The erosion has brought to light the votive objects of Mephitis sanctuary, buried for centuries, which were carried downstream by water (Gambino, 1991). Among the votive objects, the wooden findings were found during the archaeological excavations of Onorato in 1950s (Onorato, 1960; Gambino, 1991); some wooden artifacts were among those findings (Bottini et al., 1976).

\section{Materials}

The objects found in the excavation are thirteen sculptures (xoana), one ritual plate (patera) and many other worked pieces, most of which were identified as fragments of a wooden throne and some others not identified. The sculptures are dated from 6 th to 4 th century BC on the base of their style (Bottini et al., 1976). Radiocarbon analyses partially confirmed this dating (unpublished results).

In this study the xoana, the patera, eight fragments of throne and two not identified pieces were analyzed (Table 1$)$. The throne pieces have small dimensions $(<35 \mathrm{~cm})$ and all present joint elements. Most of the sculptures are small too and they don't have a clear gender indication (Fig. 1): only two of them portray clearly a man, one a woman. Only one sculpture is exceptionally big, the xoanon n. 1499, which is about $1.40 \mathrm{~m}$ high.

Before the restoration, the woods were in waterlogged conditions, because of their long burial in the wet ground nearby the riverbed, and mineralized. The minerals affecting the woods, described below, were the consequence of the presence of gases arising from the ground and diffusing also in the water sources. Some objects were immediately restored after the archaeological excavations (Augusti, 1959; Augusti, 1961) and preserved in the Museo Irpino of Avellino, partially in the exhibition hall and partially in the basement, located in a modern moldy wooden box, without any protection (Table 1). As highlighted in a previous study (Capano et al., 2012), the findings preserved in the basement were not restored or restored differently with respect to the exhibited ones: the xoanon n. 3305 is the only one showing an evident restoration work, consisting in the fixing of spare parts with glue (Capano et al., 2012).

Before the restoration, Augusti performed some chemical analyses on the materials, discovering a deep alteration of the wood, affected by a mineral permeation. According to those analyses, the organic substances still present in the wood of some analyzed finds had an amount from less than 50\%-70\%. Instead, the mineral concentration varied between $15 \%$ and $40 \%$, while in fresh wood normally it is around $1 \%$ (Augusti, 1961). The inorganic substances discovered by Augusti (1959) in wood ashes were: $\mathrm{Fe}^{3+}, \mathrm{SiO}_{2}$, sulfur and its oxidation products (e.g. $\mathrm{SO}_{4}{ }^{2-}$ and $\mathrm{S}^{-}$) and ground compounds (e.g. $\mathrm{Ca}^{2+}, \mathrm{CO}_{3}{ }^{2-}$ and $\mathrm{Cl}^{-}$).

The restoration was performed in two steps: I) removal of water with denatured alcohol, followed by consolidation in a bath of collagen glue and $\mathrm{NaF}$, used as antiseptic, and a bath in tannic acid solution at $3 \%$, in order to make the glue insoluble; II) refilling of cavities in the wood, appeared after the first step, with a wood pulp obtained by the mix of wood powder with a powder of tannin and glue (Augusti, 1959, 1961)

Because of the minerals absorbed in the Ansanto Valley and the alteration in the chemical composition, introduced by restoration, the consistency is different respect to that of a normal wood, being more similar to charcoal.

In addition to the archaeological artifacts, other woods were investigated as test samples for the chemical analyses: I) the wood of a modern deciduous oak (Quercus sp.) from Pietrastornina (named Q_Pietra, described in Capano et al. 2012), a village about $30 \mathrm{~km}$ far from the Ansanto Valley; II) the wood of a modern 
Table 1

Schematic summary of the analyzed materials (age, kind of material, provenience, conservation place and restoration presence).

\begin{tabular}{|c|c|c|c|c|c|}
\hline $\begin{array}{l}\text { Finding } \\
\text { code }\end{array}$ & Material age & $\begin{array}{l}\text { Kind of } \\
\text { material }\end{array}$ & Provenience & Conservation place & Restoration \\
\hline 1228 & \multirow{24}{*}{ Archaeological } & \multirow{10}{*}{ Xoanon } & \multirow{24}{*}{ Ansanto Valley } & \multirow{19}{*}{$\begin{array}{l}\text { Museo Irpino of Avellino } \\
\text { (exhibition hall) }\end{array}$} & \multirow{19}{*}{ Augusti $(1959,1961)$} \\
\hline 1229 & & & & & \\
\hline 1231 & & & & & \\
\hline 1233 & & & & & \\
\hline 1234 & & & & & \\
\hline 1237 & & & & & \\
\hline 1238 & & & & & \\
\hline 1243 & & & & & \\
\hline 1244 & & & & & \\
\hline 1499 & & & & & \\
\hline 1219 & & \multirow{8}{*}{$\begin{array}{l}\text { Throne } \\
\text { piece }\end{array}$} & & & \\
\hline 1221 & & & & & \\
\hline 1222 & & & & & \\
\hline 1223 & & & & & \\
\hline 1225 & & & & & \\
\hline 2472 & & & & & \\
\hline 2476 & & & & & \\
\hline 2477 & & & & & \\
\hline 1227 & & Patera & & & \\
\hline 3301 & & Not & & \multirow{5}{*}{$\begin{array}{l}\text { Museo Irpino of Avellino } \\
\text { (basement) }\end{array}$} & \multirow{5}{*}{ No indication } \\
\hline 3302 & & identified & & & \\
\hline 3303 & & Xoanon? & & & \\
\hline 3304 & & \multirow{2}{*}{ Xoanon } & & & \\
\hline 3305 & & & & & \\
\hline Q_Pietra & \multirow{3}{*}{ Modern } & \multirow[b]{2}{*}{ Tree } & \multirow[b]{2}{*}{ Pietrastornina } & \multirow[b]{2}{*}{ CIRCE laboratory } & \multirow[b]{2}{*}{ No restoration } \\
\hline C_Pietra & & & & & \\
\hline C_Ansanto & & Fence pile & Ansanto Valley & CIRCE laboratory & $\begin{array}{l}\text { No restoration/ } \\
\text { Author's restoration }\end{array}$ \\
\hline
\end{tabular}

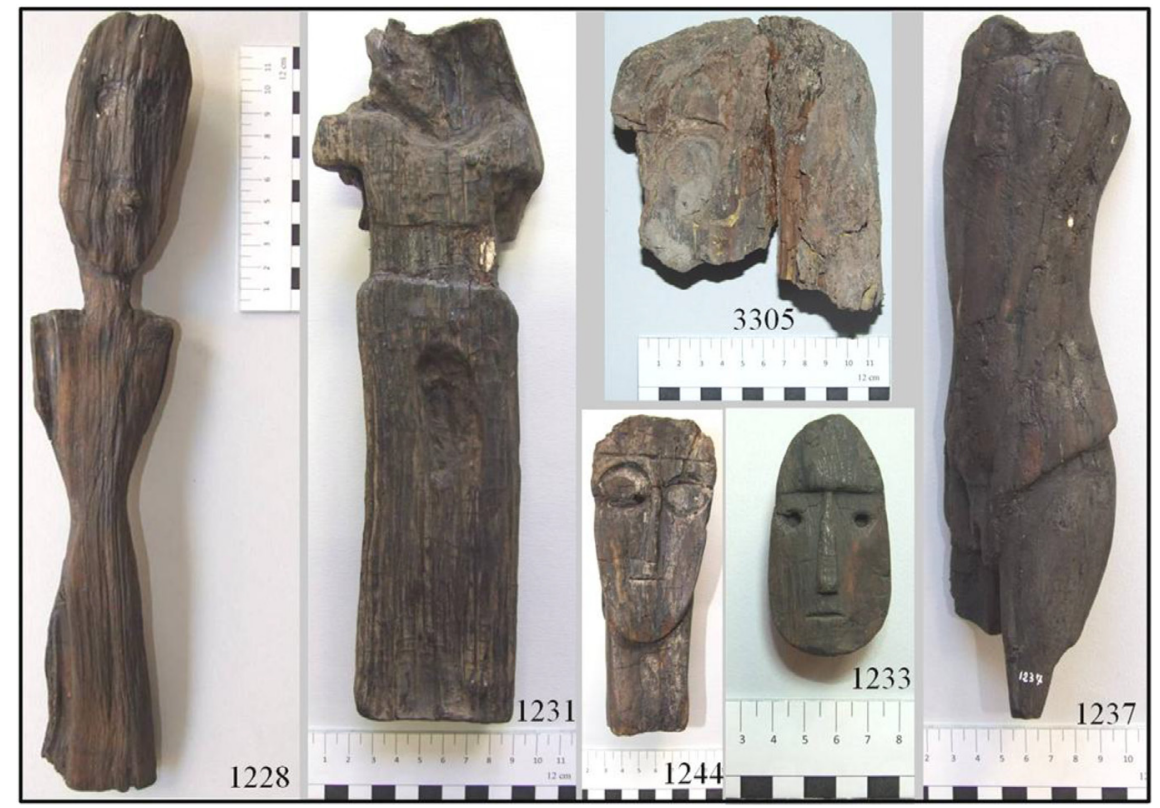

Fig. 1. Pictures of some xoana. The code of the findings is reported in the low left of each sculpture. 
chestnut (Castanea sativa Mill.) also from Pietrastornina (named C_Pietra); III) the wood of a chestnut modern fence pile found in the Ansanto Valley (named C_Ansanto), close to the main boiling lake (Table 1). The provenience of trees from which C_Ansanto wood was obtained is unknown. The fence pile was detached and felled near the lake in an unknown period. The few-ring sample comes from the external part of the pile. This wood was collected because of its presence in the Ansanto Valley for a certain amount of time (the local guide said that the fence was built in 1990s), so this wood was exposed for about 20 years to exhalations similar to the ones experienced by archaeological materials. Part of this wood was also consolidated by the authors following Augusti's procedure (Augusti, 1959, 1961), in order to compare the same wood acidity before and after the restoration.

\section{Methods}

\subsection{Sampling}

For their safety, it was not allowed to bring the objects outside the conservation place, so the analyses were performed, where possible, in a mobile laboratory housed in the Museum; only very small fragments of wood (some of $\sim 2 \mathrm{~mm}^{3}$ ) were sampled and only in some findings, because of the great historical-artistic value of the wooden objects. The sampling was performed with a surgical blade where some breaks were already present, or where a fragment was already cut, or under the basis in a hidden zone.

\subsection{Wood identification}

The first approach to the identification of wood taxa was the macroscopic analysis by means of $7 x$ and $15 x$ magnifiers, performed directly in the Museum. When this observation was fruitless, a small sample of material was taken for the microscopic analysis. The friable consistency of the woods prevented the cutting of thin section. Following the suggestion of Michael Schneider, from the Landesamt für Denkmalpflege of Hemmenhofen (Germany), the wood was rehydrated by soaking samples in ethanol and deionized water solutions. Ethanol has a surface tension lower than water, so it can easily fill the wood pores, opening the access to the water of the following baths, which allow the hydration of wood. Samples were left for $1 \mathrm{~h}$ in ethanol $100 \%$ concentration; later the ethanol solution was diluted by adding deionized water (1:1 water - ethanol). Finally other deionized water was added to the previous solution, reaching a solution of about 4:1 water - ethanol. The samples were left in the solution overnight (sometimes also 2 days); than it was possible to cut thin sections with razor blades and look at the anatomy of the wood by means of transmitted light microscope. When the very little amount of available samples or their high degree of damage did not allow identifying the species with optical microscopy, samples were analyzed by SEM. The anatomical characters recognized allowed the identification of the taxa thanks to the comparison with wood atlases (Jacquiot et al., 1973; Schweingruber, 1990; Nardi Berti, 1994; Abbate Edlmann et al., 1994).

\subsection{Preservation state}

A preliminary macroscopic analysis was performed in order to investigate the state of preservation of the artifacts. The investigation was then completed by means of microscopic techniques and chemical analyses.

Microscopic analysis was performed with optical microscope, polarizing microscope and SEM. The findings, from which a wood fragment was sampled, were observed under the optical microscope at several magnifications for wood species identification. During this analysis also some information about the wood conservation state were obtained. Only the wood of the finding n. 1219 was observed under microscope with polarized light, in order to highlight cellulose presence. The thin sections for the analysis of this wood were sliced after the freezing of the sample on cold plate, followed to an ethanol and water bath (see previous paragraph), and manual cutting with razor blade. Findings n. 1219, 1229, 1237, 2477, 3304 and 3305 (4 restored findings and 2 "non-restored" ones; Table 1) were analyzed with SEM, which has better visible magnifications, in order to investigate the kind of damage of the woods. The woods were firstly covered by a gold film of $15 \mathrm{~nm}$ thickness, realized under vacuum (in Argon surface) in about $90 \mathrm{~s}$ within the Balzers SCD 004 system of CNR-IVALSA (Sesto Fiorentino - FI, Italy). The samples were later analyzed with Philips XL 20 SEM system of CNRIVALSA.

The chemical analyses performed concern the measurement of $\mathrm{pH}$ and ash contents and the investigation of chemical composition of wood by means of FTIR-ATR spectroscopy.

The $\mathrm{pH}$ was measured in the wood of xoanon $\mathrm{n} .1219$ and in the wood of Q_Pietra, belonging to the same wood genus of the archaeological wood, in order to compare a restored wood with a non-restored one; a non-restored archaeological oak wood from the Ansanto Valley was not available, so Q_Pietra was used instead of it. C_Ansanto wood was also analyzed, before and after our restoration, because it was subjected to the same minerals as the archaeological woods were. C_Ansanto pHs were compared to a chestnut wood grown in Pietrastornina (C_Pietra), so not affected by the exhalations. Only the wood of one archaeological finding was analyzed, because of the little material available. About $50 \mathrm{mgs}$ of each sample were put in a different beaker with $25 \mathrm{ml}$ of deionized water at atmospheric temperature. A Mettler Toledo $\mathrm{pH}$ meter instrument, with an error of \pm 0.25 , was used for the measurements. The $\mathrm{pH}$ of the water containing the samples was measured two times: the first one after $2 \mathrm{~h}$ and the second one after $4 \mathrm{~h}$, in order to check possible variations in the time.

In order to have a confirmation about the degree of mineral permeation of the woods, already measured by Augusti (Augusti, 1961), the ash percentage was measured in the wood of finding n. 3305. Only this wood was analyzed, because of the little amount of material available for the other findings. The ash content of C_Ansanto wood was measured too, despite the big difference in terms of time and position between the modern (about 20 years on the site) and the archaeological woods (buried for more than two millennia). This last measurement was not done to compare the two samples, but only to estimate the mineral permeation capacity of the site on wood material. $563 \mathrm{mg}$ of xoanon $\mathrm{n} .3305$ and $643 \mathrm{mg}$ of C_Ansanto were dried in muffle furnace at $105^{\circ} \mathrm{C}$ for $24 \mathrm{~h}$. They were then weighted and after burnt at $525{ }^{\circ} \mathrm{C}$ for $2 \mathrm{~h}$ in muffle furnace, following a modified TAPPI T211 procedure (Tappi, 1993). At the end, they were weighted again and the percentage of reduction was calculated.

The wood of restored (n. 1219, 1223, 1227, 1228, 1229, 1237 and 2477) and non-restored (n. 3304 and 3305) findings was analyzed by FTIR (Fourier transform infrared) spectroscopy. Q_Pietra sample was also analyzed for comparison, because its wood belongs to the same species of most of archaeological samples. A Bruker Optics - Alpha FTIR spectrometer, equipped with a system of sample reading in attenuated total reflectance (ATR) with diamond crystal (Bruker Optics - Alpha-P), was used. The acquisition was carried out in the spectral range between 4000 and $400 \mathrm{~cm}^{-1}$ with a resolution of $4 \mathrm{~cm}^{-1}$, mediating 
Table 2

Results of wood identification and state of preservation analysis (macroscopic, microscopic and FTIR general results).

\begin{tabular}{|c|c|c|c|c|}
\hline \multirow[b]{2}{*}{ Finding } & \multirow{2}{*}{$\begin{array}{l}\text { WOOD SPECIES } \\
\text { IDENTIFICATION } \\
\text { Taxon }\end{array}$} & \multicolumn{3}{|c|}{ STATE OF PRESERVATION ANALYSIS } \\
\hline & & Macroscopic analysis & Microscopic analysis & FTIR analysis \\
\hline 1228 & \multirow[b]{2}{*}{ Quercus sp. } & \multirow{18}{*}{$\begin{array}{l}\text { Hard and compact } \\
\text { aspect }\end{array}$} & $/$ & Advanced level of decay \\
\hline 1229 & & & \multirow{5}{*}{$\begin{array}{l}\text { Deformation of } \\
\text { anatomical characters }\end{array}$} & $\begin{array}{l}\text { a) Good state of } \\
\text { preservation } \\
\text { b) Advanced level of decay }\end{array}$ \\
\hline 1237 & Rosaceae (Sorbus sp.) & & & \\
\hline 1219 & \multirow{4}{*}{ Quercus sp. } & & & Degraded \\
\hline 1227 & & & & \\
\hline 1222 & & & & / \\
\hline 1231 & & & \multirow{3}{*}{ / } & \multirow{3}{*}{ / } \\
\hline 1233 & \multirow{2}{*}{1} & & & \\
\hline 1234 & & & & \\
\hline 1238 & \multirow{3}{*}{ Quercus sp. } & & \multirow{5}{*}{ / } & \multirow{5}{*}{1} \\
\hline 1243 & & & & \\
\hline 1499 & & & & \\
\hline 1244 & Rosaceae & & & \\
\hline 1221 & Fagus silvatica $\mathrm{L}$. & & & \\
\hline 1223 & \multirow{2}{*}{ Quercus sp. } & & \multirow{2}{*}{ / } & Degraded \\
\hline 2472 & & & & $/$ \\
\hline 1225 & \multirow{2}{*}{ Porous ring hardwood } & & \multirow{2}{*}{ / } & \multirow[b]{2}{*}{1} \\
\hline 2476 & & & & \\
\hline 3301 & \multirow{2}{*}{ Hardwood } & \multirow{4}{*}{$\begin{array}{l}\text { Compact, but fragile } \\
\text { aspect }\end{array}$} & \multirow{3}{*}{ I } & \multirow{3}{*}{1} \\
\hline 3302 & & & & \\
\hline 3303 & Porous ring hardwood & & & \\
\hline 2477 & Quercus sp. & & $\begin{array}{l}\text { Deformation of } \\
\text { anatomical characters }\end{array}$ & $\begin{array}{l}\text { Very advanced level of } \\
\text { decay }\end{array}$ \\
\hline 3304 & \multirow[t]{2}{*}{ Populus/Salix } & \multirow[t]{2}{*}{$\begin{array}{l}\text { Not compact and fragile } \\
\text { aspect }\end{array}$} & $\begin{array}{l}\text { Deformation of } \\
\text { anatomical characters. } \\
\text { Presence of modern } \\
\text { mold }\end{array}$ & Advanced level of decay \\
\hline 3305 & & & $\begin{array}{l}\text { Deformation of } \\
\text { anatomical characters }\end{array}$ & Degraded \\
\hline
\end{tabular}

among 40 successive scans. Spectra were acquired and processed using the software OPUS 6.5 (Bruker Optics 1997-2007). In order to preserve the samples entire for the following ${ }^{14} \mathrm{C}$ measurement (unpublished results), they were not pulverized for the FTIR analysis. Each sample was measured three or more times, in order to check the reproducibility of measurement. At the end one spectrum was chosen for each sample when the replications were equal, otherwise more than one spectrum for sample was analyzed.

Cellulose and hemicelluloses are mostly highlighted by stretching signals of $\mathrm{C}-\mathrm{O}-\mathrm{C}$ bond, with a high peak at about $1026 \mathrm{~cm}^{-1}$ and peaks of low intensity (attributable to different groups) around 1734, 1370, 1315, 1240, 1160, 1110 and $898 \mathrm{~cm}^{-1}$. The bands characterizing lignin are present at about 1590, 1509 and $1422 \mathrm{~cm}^{-1}$, due to aromatic skeletal vibrations; 1265 and $1217 \mathrm{~cm}^{-1}$ due to CO vibration in guaiacyl units; 1140 and $1459 \mathrm{~cm}^{-1}$ due to $\mathrm{CH}$ deformations in guaiacyl rings (Faix, 1986; Schultz and Glasser, 1986; Faix, 1991; Evans et al., 1992; Kajihara et al., 1993; Pandey, 1998; Rodrigues et al., 1998; Silverstein and Webster, 1999; Schwanninger et al., 2004). Samples were analyzed in the spectra range from 600 to $1800 \mathrm{~cm}^{-1}$, checking the presence of the spectra typical of the main wood components (holocellulose and lignin).

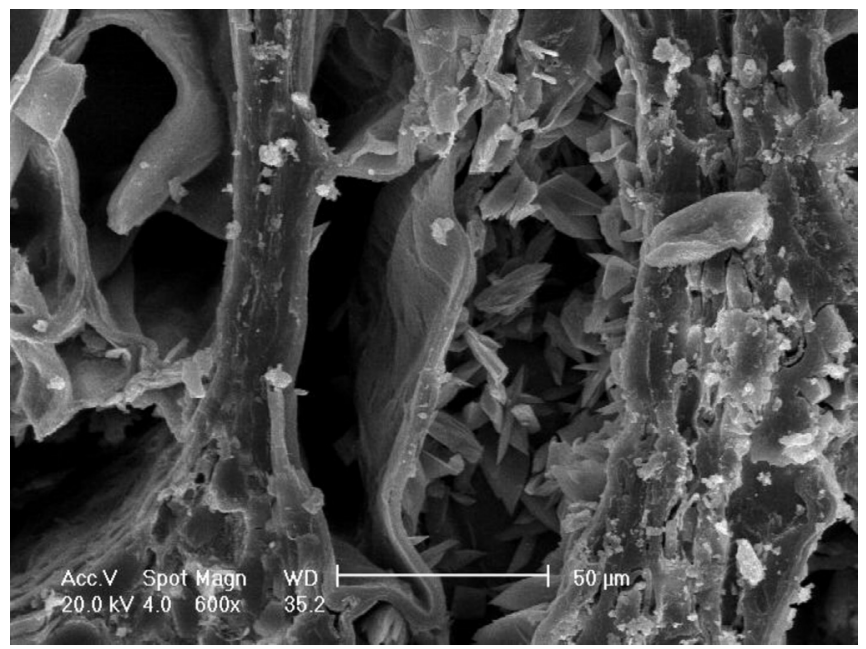

Fig. 2. Transversal section of finding n. 1219: the vessels are crushed in the tangential direction. Crystals of salt are also visible in cell lumens. 


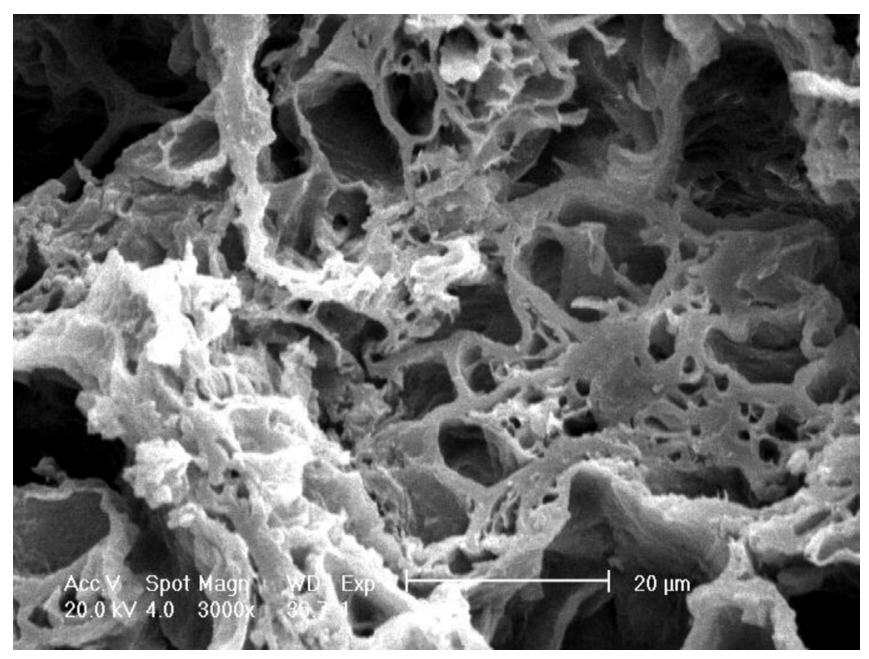

Fig. 3. Transversal section of the finding n. 3304: the cells in the transversal section are largely distorted. The degraded walls lost the usual shape and, because of collapses and deformations, many cells are not distinguishable from those neighboring.

\section{Results}

\subsection{Wood identification}

Wood anatomy study allowed the identification of wood taxa, sometimes the wood species, of most of the archaeological findings. Four different taxa have been identified with certainty among all the findings (Table 2). The presence of ring-porous and uniseriate and multiseriate rays led to the identification of Quercus sp. genus in findings $1228,1229,1231,1238,1243,1499,1219,1223,1227$, 2472 and 2477 (Table 2); the fragment sampled from the finding $\mathrm{n}$. 1222 belongs with high probability to genus Quercus sp. too, but the small sample size did not ensure a complete certainty about this identification. The finding n. 1221 was identified as Fagus sylvatica L. thanks to the presence of diffuse-porous and uniseriate to multiseriate rays (Table 2). Diffuse-porous (isolate vessels with spiral thickening and simple perforation) and uniseriate and biseriate rays led to Rosaceae family identification for the findings n. 1237 (probably a Sorbus aucuparia L., looking at Abbate Edlmann et al.

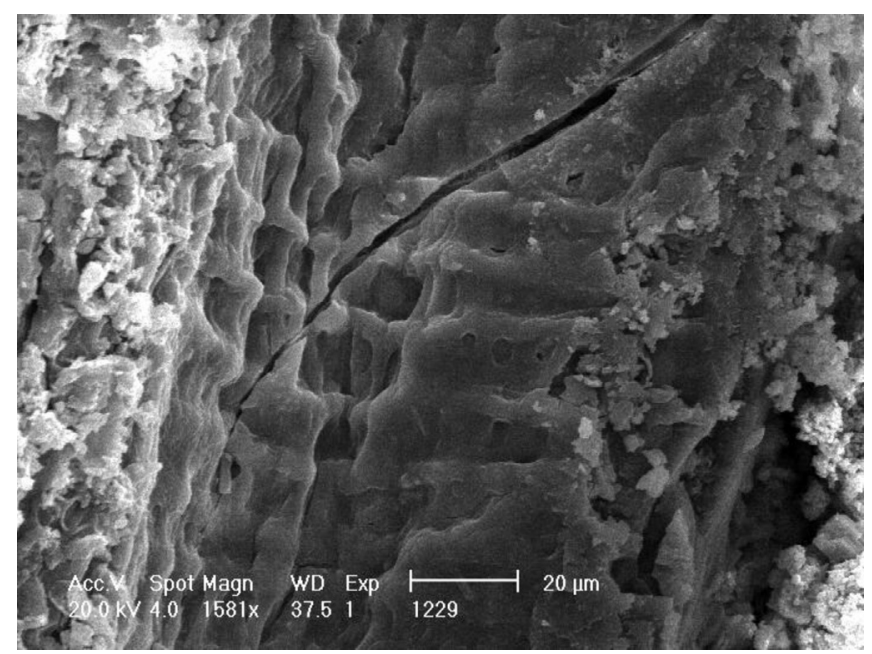

Fig. 4. Cross fields in radial section of finding n. 1229: a sort of patina, probably constituted of the materials of restoration, covers the anatomical characters of wood; it has a fracture dangerous for wood stability.

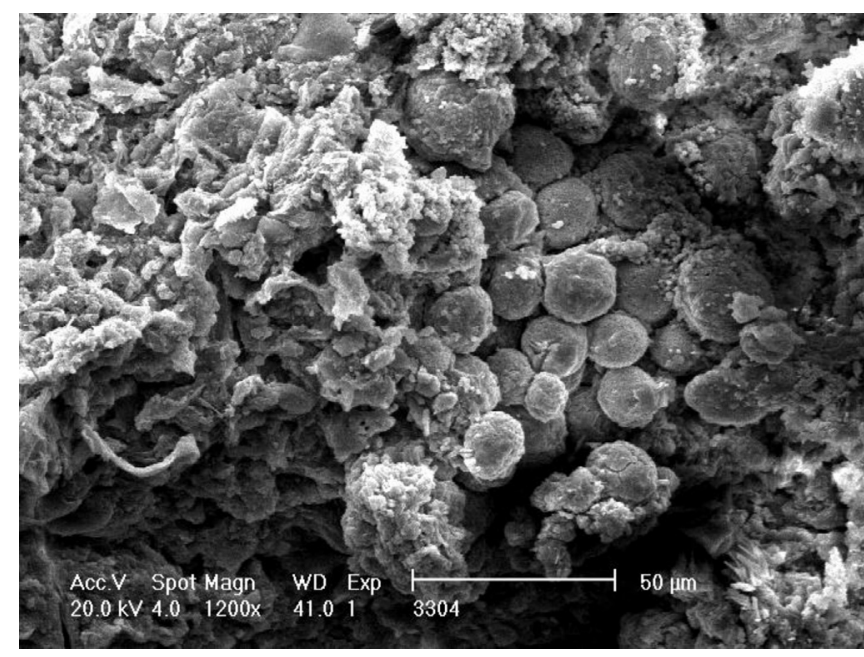

Fig. 5. Longitudinal section of finding n. 3304: an unknown material, not pertinent to wood anatomy, is visible. Considering the conservation place of this finding, this element can be identified as modern mold.

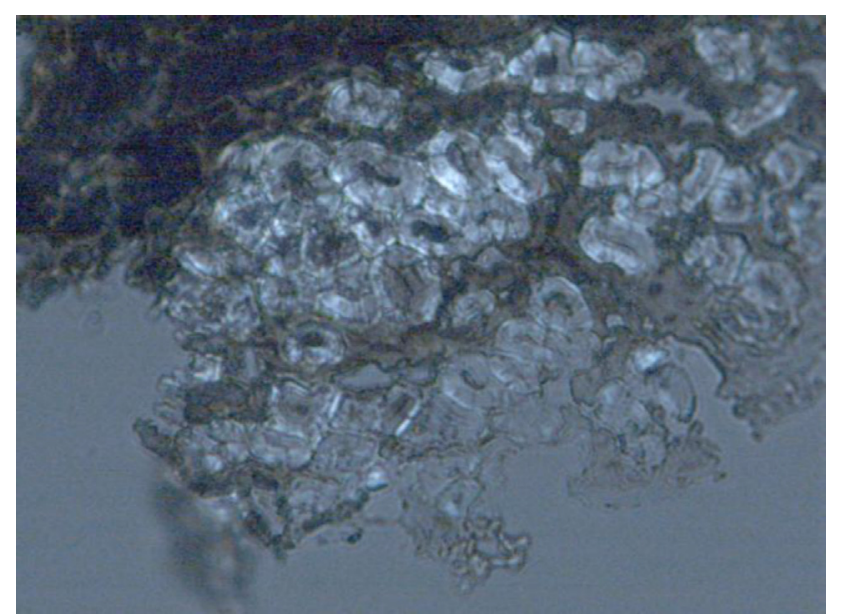

Fig. 6. Fibers on transversal section of finding n. 1219, observed under polarized light microscope. The white color part indicates the residual crystalline cellulose.

1994) and for 1244 (Table 2). The uniseriate and partially biseriate rays, diffuse-porous, simple perforations and ray-vessel pits of the cross fields of Populus/Salix were recognized in findings n. 3304 and 3305 (Table 2).

The wood of some findings was not identified, because samples were too small, thus it was impossible to determine if the lack of

Table 3

Results of wood pH (measured after 2 and $4 \mathrm{~h}$ in water) and of moisture content of oven dry wood (after drying at $105^{\circ} \mathrm{C}$ ) and ash (after the combustion at $525^{\circ} \mathrm{C}$ ) percentages.

\begin{tabular}{lllll}
\hline Finding & $\mathrm{pH}(2 \mathrm{~h})$ & $\mathrm{pH}(4 \mathrm{~h})$ & $\begin{array}{l}\text { \% Moisture } \\
(\text { drying at } \\
\left.105{ }^{\circ} \mathrm{C}\right)\end{array}$ & $\begin{array}{l}\% \text { Ash } \\
(\text { combustion } \\
\left.\text { at } 525{ }^{\circ} \mathrm{C}\right)\end{array}$ \\
\hline C_Pietra & 5.11 & 5.30 & & \\
C_Ansanto & 3.51 & 3.49 & 8 & 8 \\
C_Ansanto_restored & 3.43 & 3.42 & & \\
Q_Pietra & 5.25 & 4.91 & & 18 \\
1219 & 3.87 & 3.88 & & \\
3305 & & & 21 & \\
\hline
\end{tabular}




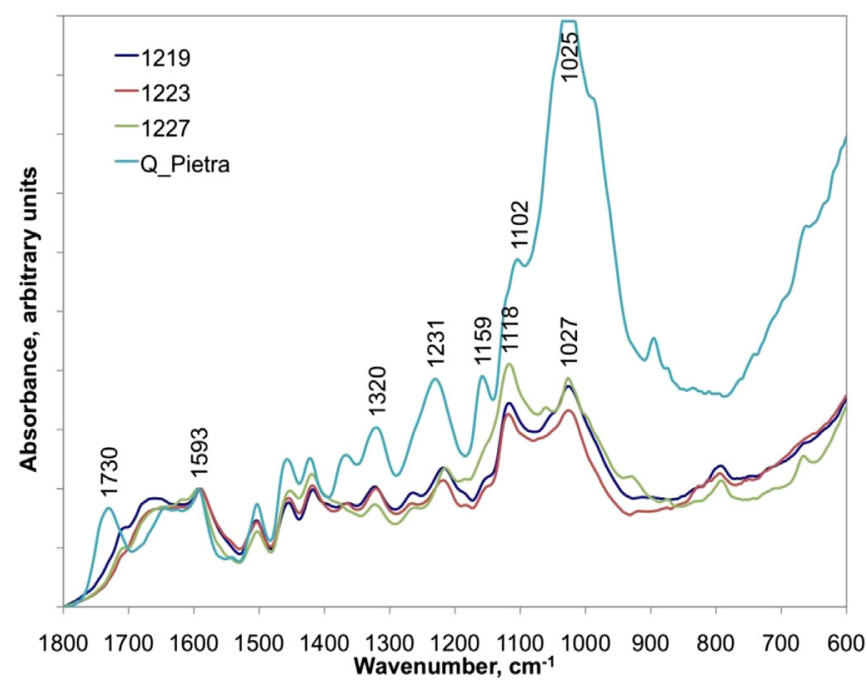

Fig. 7. FTIR spectra of the wood of findings n. 1219, 1223, 1227 and Q_Pietra. Some peaks of polysaccharides and lignin are highlighted with the wave number indication (see paragraph 5.2). The spectra were min-max normalized between 1500 and $1800 \mathrm{~cm}^{-1}$.

any anatomical feature was due to the smallness of the sample or to wood species features themselves. In particular, anatomical features of findings n. 1233 and 1234 were not visible due to the thick layer of restoration material; the findings n. 3301 and 3302 showed the presence of vessels, leading to the identification of wood as a hardwood, but it was not possible to identify the genus or the family; the wood of findings n. 3303, 1225 and 2476 showed the presence of diffuse-porous, but no deeper analysis was possible. The wood of the arm of finding n. 1499 was identified as a broadleaf with diffuse-porous wood, so different compared to the one used for the body. The wood anatomy distortions were a problem too for wood identification. Some characters typical of a taxon, in fact, may have been destroyed (e.g. scalariform plates); moreover they may be so much compressed to drive to wrong interpretation (e.g. the wood could show a diffuse porosity instead of a semi-ring one).

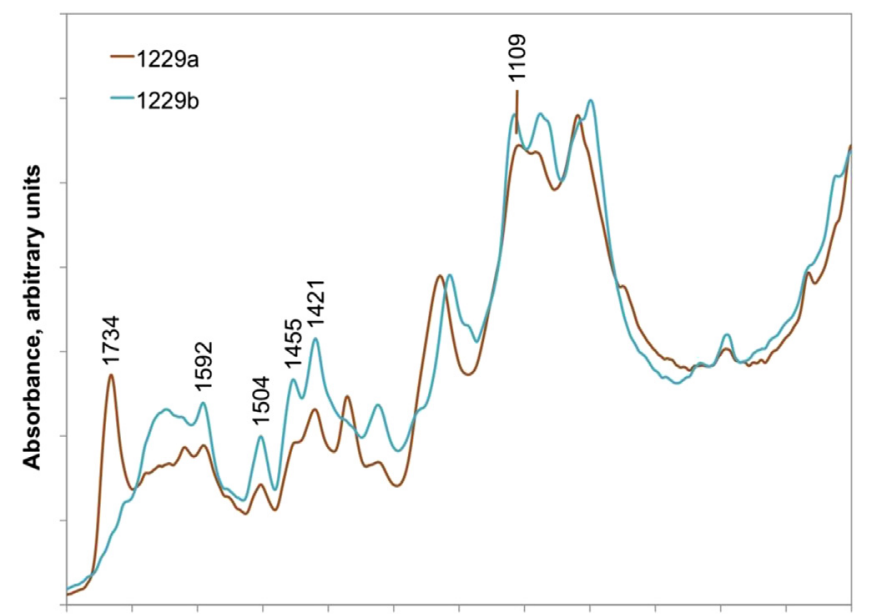

$\begin{array}{lllllllllll}1800 & 1700 & 1600 & 1500 & 1400 & 1300 \quad 1200 \quad 1100 & 1000 & 900 & 800 & 700 & 600\end{array}$

Fig. 8. FTIR spectra of two different portions of the wood of finding n. 1229. Peaks of lignin and of an unknown material (extraneous to wood) are highlighted with the wave number indication (see paragraph 5.2).

\subsection{Preservation state}

Observing the findings without the support of microscopic magnifications, the "non-restored" ones (3301, 3302, 3303, 3304 and 3305) all appeared fragile and, in some cases, not compact (the xoana n. 3304 and 3305 can easily break; Table 2). All the others analyzed, exhibited in the museum, appeared to be mostly hard and compact, despite numerous fractures and outcropping salts (Table 2). A longitudinal compression (from a side to the other of the objects) of the sculpture wood was visible by comparing the carvings with their pictures before the restoration (Augusti, 1961).

Microscopic analyses showed a deformation of wood anatomical characters: vessels and rays are not only collapsed along the tangential direction (as visible in findings n. 1219, 1222, 1227, 1229, 1237 and 3305; Fig. 2), but also often completely distorted (as visible in findings n. 1219, 1222, 3304 and 3305; Fig. 3); in both cases this is caused by the almost total disappearance of cellulose from the walls. In a few samples, an undefined substance (probably a patina of restoration) completely covers the anatomical features (as in findings n. 1229 and 2477), obstructing the view of cell walls, if present. In finding $\mathrm{n} .1229$ this possible patina presents fractures (Fig. 4). Some non-woody spheres are deposited on the surface of finding n. 3304. Considering that this wood was preserved in a moldy wooden box in the basement of the museum, it is possible to argue that this non-identified material can be the mold of the box (Fig. 5). The polarized light microscope analysis indicated the degradation of cellulose, which crystalline part is highly reduced (white color parts in Fig. 6).

The two $\mathrm{pH}$ values measured for each sample agree within the experimental error (Table 3). With regard to the analysis of chestnut woods, C_Ansanto is characterized by a higher acidity respect to C_Pietra, but the $\mathrm{pH}$ value of C_Ansanto restored and non-restored is the same, indicating that the restoration did not alter the acidity of wood (Table 3). Concerning oak woods, the acidity of the archaeological finding is higher than in modern Q_Pietra (Table 3).

The percentage of mineral permeation of the archaeological wood is considerable (Table 3), even if it does not reach the maximum values described by the restorer (40\%; Augusti, 1961). C_Ansanto wood is also mineral permeated, but in a lower percentage respect to the archaeological wood.

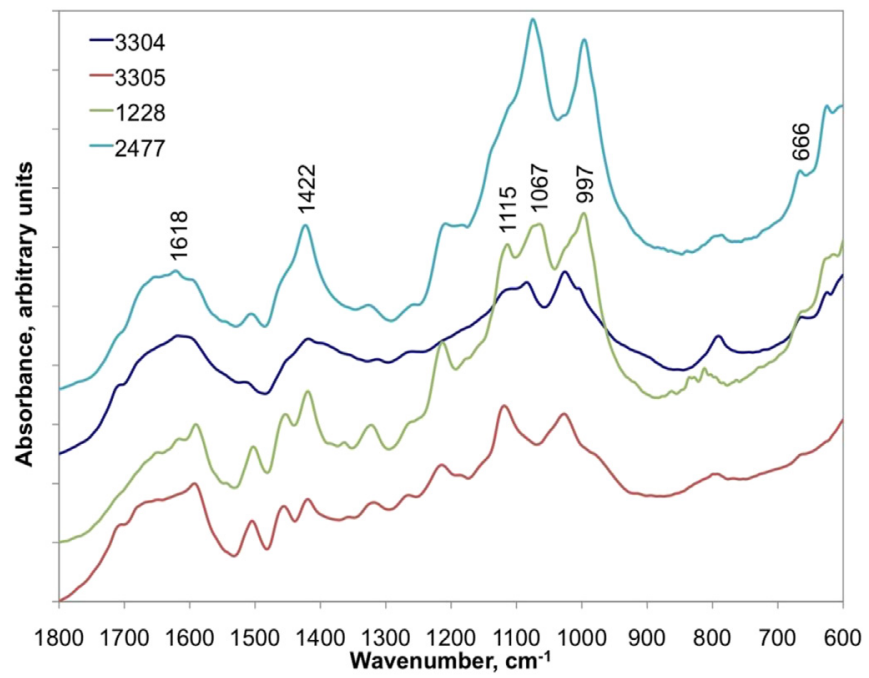

Fig. 9. FTIR spectra of the wood of findings n. 1228, 2477, 3304 and 3305. Peaks of sulfates, tannin and lignin are highlighted with wave number indication (see paragraph 5.2). The spectra were min-max normalized between 1500 and $1800 \mathrm{~cm}^{-1}$. 
The FTIR spectra of findings n. 1227, 1219 and 1223 (all made of oak wood) present almost all the peaks characteristic of lignin, while no peak of cellulose is visible (Fig. 7). In fact, the bands at 1026, 1110, 1235, 1320, 1370 and $1734 \mathrm{~cm}^{-1}$, all attributable to polysaccharides (Schwanninger et al., 2004) and well-evident in non-degraded oak wood of Pietrastornina (Fig. 7), are almost completely disappeared in the archaeological material. In these findings, the dominating bands are those at $1120 \mathrm{~cm}^{-1}$ and at $1030 \mathrm{~cm}^{-1}$, attributed to aromatic $\mathrm{CH}$ in plane deformation, and hence to lignin (Faix, 1991); while in non-degraded wood these same bands are hindered by the very high intensity of the polysaccharides at $1026 \mathrm{~cm}^{-1}$ (Fig. 7).

The same lignin-related bands detected in samples 1227, 1219 and 1223 are also visible in Fig. 8, which shows two spectra obtained in the same finding n. 1229. The two spectra of 1229 are appreciably different. In 1229b the main bands of lignin (at 1590, 1509,1422 and $1459 \mathrm{~cm}^{-1}$, all related to aromatic vibrations) are preponderant, thus evidencing the practical depletion of polysaccharides and hence a bad state of preservation, with a level of decay similar to that of findings 1227,1219 and 1223. In contrast, 1229a shows a better state of wood preservation: almost all the peaks of cellulose $\left(1026,1110,1235,1320,1370\right.$ and $\left.1734 \mathrm{~cm}^{-1}\right)$ are still present, although sometimes slightly shifted (most probably due to changes in the molecule structure), whereas the main peaks of lignin evidenced less intense vibrations. The band at $1734 \mathrm{~cm}^{-1}$ (ester group, with $\mathrm{C}=\mathrm{O}$ bond), usually attributed to hemicelluloses, is one of the first to disappear because of wood degradation. Therefore, in the case of 1229a both its presence and its intensity is probably related to the addition of extraneous to wood materials, for instance during the restoration. An analogous consideration can be also made for the band at $1109 \mathrm{~cm}^{-1}$.

The comparison among the spectra of the worst preserved woods (findings n. 3304, 3305, 1228 and 2477) is shown in Fig. 9. Sample 3305, the less decayed among them, shows only the bands attributable to lignin, and its spectrum is quite similar to those already shown in Figs. 7 and 8. In sample 1228, while most of bands are common to those of 3305 , a new band at $1070 \mathrm{~cm}^{-1}$ appears close to that one at $1120 \mathrm{~cm}^{-1}$ (Fig. 9). This band was not related to lignin, but it has been associated to vibrations of the $S=0$ groups, indicating the presence of sulfoxides or sulfates (Colthup et al., 1990). In sulfates, this band (attributable to asymmetric $\mathrm{SO}_{4}$ stretching) is also associated to a smaller band at $997 \mathrm{~cm}^{-1}$ and to the bending vibration at $665 \mathrm{~cm}^{-1}$ (Bobos et al., 2006). Both bands (997 and $665 \mathrm{~cm}^{-1}$ ) are also present in the spectrum of 1228 .

In sample 3304 the lignin band at $1120 \mathrm{~cm}^{-1}$ becomes a shoulder, and only the lignin bands at $1026 \mathrm{~cm}^{-1}$ and $1422 \mathrm{~cm}^{-1}$ are present; in contrast, the bands at $1217 \mathrm{~cm}^{-1}$ and $1459 \mathrm{~cm}^{-1}$ dramatically decrease, whereas the ones at $1320 \mathrm{~cm}^{-1}$ and even $1505 \mathrm{~cm}^{-1}$ are only shoulders. The broadening of signals can be an effect of molecule rearrangements and depolymerization: for instance, the broad band centered at $1616 \mathrm{~cm}^{-1}$ has been reported for wood tannins (Fengel, 1991). All these occurrences evidenced that the wood of 3304 is even more decayed than the one of 3305 and 1228. Finally, the wood of the finding n. 2477 presents the worst state of preservation among all analyzed findings. In fact, even the bands characteristic of lignin are almost completely lost or they became only shoulders: the only clear lignin peak are the ones at $1422 \mathrm{~cm}^{-1}$, and the broad band centered at $1616 \mathrm{~cm}^{-1}$, whereas the bands at 1070 and $997 \mathrm{~cm}^{-1}$ are predominant (Fig. 9).

\section{Discussion}

Among the four wood taxa identified, the most frequent wood resulted oak (deciduous oak), tree present also nowadays in the Ansanto Valley. Oak is a tree diffuse over the whole Apennine
Mountains at lower altitude, so its presence in the Ansanto Valley does not ensure the provenience of archaeological wood from the valley. Moreover, the sanctuary in the Ansanto Valley was very famous and people from different areas came to venerate the goddess, as the discovery of coins testifies (Bottini et al., 1976; Grande, 2008). If we divide the analysis of xoana on one hand and the other finding analysis on the other hand, 3 are the wooden groups identified for the sculptures and more than 2 among the other finds. Concerning the xoana analysis, the choice of wood species related to wood properties may not be taken into account in this context: the sacredness of the objects must have required the use of species sacred to the goddess, rather than species with special technical properties. The use of three kinds of trees for the xoana carving (Table 2), instead of the expected one, leads to two possible explanations: I) three or more were the wood species sacred to the goddess and II) the faithful choice is related to wood availability, without any correlation with a wood sacred to the goddess.

The presence of two species of wood in the same finding is attested only in xoanon n. 1499, where the arm wood is different respect to the body. Looking at the pictures left by the restorer, the xoanon had no arm before the restoration (Augusti, 1959). It means that the restorer introduced the arms to replace the original presence or because of the traces of cavities that the restorer thought belonging to the location of arms, but without knowing their original form.

Concerning the preservation state, the restored artifacts appear mostly hard and compact; while the non-restored ones are fragile and, in some cases, easy to break (Table 2). The microscopic analysis evidenced a general deformation of anatomical characters, with the anatomical structure (vessel and ray cells) crushed in the tangential direction and deformed. The crushing can be attributed to the compression, which the findings have been subjected to during the years of burial or caused by the drying of wood during the first phase of consolidation; while the deformation of the cells derives from the destruction of cell wall, determined by the degradation of lignin and especially cellulose (as highlighted both by polarized light microscope results and by spectroscopic measurements), most likely caused by the attack of microorganisms, such as fungi and bacteria. Unfortunately the lost of visibility of cell walls did not allow the identification of the responsible microorganisms. The presence of fractures in the wood and in the probable patina of restoration could turn in a danger for the preservation of the objects.

The chemical analyses took into consideration only part of the examined objects, but a general idea about the state of preservation of these objects emerged (Table 2). The pH analysis indicates a higher acidity in woods from the Ansanto Valley than in woods from Pietrastornina, both for chestnut and oak woods. This result is probably ascribable to the low $\mathrm{pH}$ of the Ansanto Valley soil and to the inorganic substances that permeated the buried woods increasing their acidity. Moreover, $\mathrm{pH}$ measurements have also shown how the restoration process did not affect the acidity: no difference in the acidity of C_Ansanto wood has been measured before and after the restoration. In any case, a possible alteration of $\mathrm{pH}$ value in the restored archaeological woods could have occurred due to the aging of the consolidation materials (not analyzed in this study).

The degree of mineral permeation of the archaeological wood is very high (specifically taking into account the results from Augusti). The increase of the mineral content, substituting the organic fraction, occurred in the time of wood burial into the soil of the valley. Our data show how the only 20 years of C_Ansanto gas exposition were sufficient to reach an appreciable content of the inorganic fraction. However, the modern wood has a lower mineral 
permeation degree than the archaeological one, as a consequence of the different conditions and period of storage in the Ansanto Valley ground.

FTIR analysis highlighted a general deterioration of wood tissues (Table 2). Cellulose completely disappeared in almost all the findings, while lignin composition changed among the analyzed samples: the best preserved woods (although they are not in a good state of preservation) resulted those of findings n. 1237, 1219, 1223 and 1227, where cellulose is no more present, but at least the main components of lignin are still well recognizable.

In finding 1229 a strong gradient in wood decay was detected, with the part called 'a' being in a quite good state of preservation (with the bands of polysaccharides still recognizable) and the part called ' $b$ ' having a decay level comparable to the other analyzed material. In contrast, by analyzing the worst preserved wood, belonging to the findings $n$. 2477, 1228 and 3304, the molecule rearrangements and depolymerization of lignin has been associated to the presence of sulfates, thus letting hypothesize a negative effect of the preservation environment (very rich in sulfur compounds) on the long-term state of preservation of findings. However, an important contribution (perhaps synergic) to the wood tissue decay could be also imputable to recent attacks of organisms, as the probable mold discovered in the finding $n$. 3304 suggests.

It appeared form present study that the analyzed woods were highly decayed and, most importantly, they have a particular chemical composition which distinguishes them from the wet wood usually buried in soils and discovered in archaeological excavations. Although the aim of our work was not of establishing when this decay has occurred (which was not possible, basing on the available information), the question whether the decay must be imputed to the preservation conditions during burial or has mostly developed after previous consolidation deserves of being at least briefly discussed. As a matter of fact, the analyzed objects were not only wet, but also highly permeated of minerals (including sulfur compounds) before the restoration (Augusti, 1959). We have also seen that woods preserved in the Ansanto valley environment showed higher acidity than the same species collected from other sites. Moreover, wood acidity, as well as the presence of minerals, can alter the interaction of wood with the consolidating materials over time. On the other hand it is known from other fields that consolidation with collagen glue can generate rapid degradation of gelatin depending on the environmental conditions (Rivers and Umney, 2003). Therefore, we can suggest here that the particular environmental conditions where the artifacts were preserved during their burial induced serious decay in the wood tissue, and that decay proceeded faster in the objects exposed in the museum without any treatment than in those treated. At the same time, perhaps, the specific consolidation process adopted 55 years ago did not completely stop the decay in wood, although apparently it contributed to at least slow it down. As a specific suggestion related to the analyzed objects, we can affirm that (at least) some of these objects need to be treated in some way.

\section{Conclusions}

In this study some wooden artifacts from Mephitis sanctuary in the Ansanto Valley were analyzed. The wood taxa and the state of preservation of these objects were investigated by means of anatomical and chemical studies. Deciduous oak is the most diffuse carved tree. Four taxa have been identified among all the analyzed findings; three of them just among the xoana, indicating that, if a correlation between the goddess worship and the wood species existed, almost three trees were sacred to Mephitis (Quercus sp., Rosaceae and Populus/Salix taxa), not only one.
A general damage affects the wooden materials (especially the non-restored artifacts) as their degree of mineral permeation and the degradation of cellulose highlighted. It was not possible to identify the microorganisms responsible of wood deterioration; in any case, a conservative intervention on non-restored woods is strongly recommended. While the state of conservation of the restored wood of findings exhibited in the museum should be monitored in the coming years (e.g. performing periodically spectroscopic investigation), in order to detect if those woods underwent the degradation before the restoration - and the restoration stopped the process - or if the degradation process is still ongoing.

\section{Acknowledgment}

We wish to thank the Archaeological Superintendency of Salerno, Avellino, Benevento, and Caserta, who allowed the study of the artifacts; Mr Michael Schneider from the Landesamt für Denkmalpflege Baden-Württemberg (Hemmenhofen - DE) for his indispensable contribution to pinpoint of the procedure for the identification of wood species; Dr. Lorena Sozzi and Dr. Elisa Pecoraro from CNR-IVALSA (Sesto Fiorentino - Italy) for their help in using IVALSA instruments; the provincial Museo Irpino of Avellino for the hospitality and material support provided during the analyses conducted inside the museum; and finally Alfonso de Concilio, once restorer of the Archaeological Superintendency, whose kindness, cheerfulness and professionalism, while assisting us during the archaeological material sampling, we will never forget.

\section{References}

Abbate Edlmann, M.L., De Luca, L., Lazzeri, S., 1994. Atlante anatomico degli alberi ed arbusti della macchia mediterranea. Firenze.

Acanfora, M.O., 1970. Manufatti di legno di Polada e di Barche di Solferino. In: Bullettino di paletnologia italiana, vol. 79/2, pp. 157-241.

Augusti, S., 1959. Traitment de conservation de qualches objects de fouilles en bois In: Etudes de Conservation, vol. IV/4, pp. 146-151.

Augusti, S., 1961. Restauro e conservazione degli oggetti lignei. In: VII congresso Internazionale di Archeologia Classica I, Atti, pp. 183-188.

Blanchette, R.A., Ceasa, K.R., Abad, A.R., Koestler, R.J., Simpson, E., Sams, G.K., 1991 An evaluation of different forms of deterioration found in archaeological wood. Int. Biodeterior. 28, 3-22.

Blanchette, R.A., 2000. A review of microbial deterioration found in archaeological wood from different environments. Int. Biodeterior. Biodegrad. 46, 189-204.

Bobos, I., Durães, N., Noronha, F., 2006. Mineralogy and geochemistry of mill tailings impoundments from Algares (Aljustrel), Portugal: implications for acid sulfate mine waters formation. J. Geochem. Explor. 88 (1/3), 1-5.

Bottini, A., Rainini, I., Isnenghi Colazzo, S., 1976. Valle d'Ansanto. Rocca S. Felice (Avellino). Il deposito votivo del santuario di Mefite. Not. degli scavi Antich. 30, 359-524.

Caneva, G., Nugari, M.P., Salvadori, O., 2007. La biologia vegetale per i Beni Culturali. Biodeterioramento e Conservazione I. Firenze.

Capano, M. Marzaioli, F., Passariello, I., Pignatelli, O., Martinelli, N., Gigli, S., Gennarelli, I., De Cesare, N., Terrasi, T., 2012. Preliminary radiocarbon analyses of contemporaneous and archaeological wood from the Ansanto Valley (southern Italy). Radiocarbon 54 (3-4), 701-714.

Capano, M., Altieri, S., Marzaioli, F., Sirignano, C., Pignatelli, O., Martinelli, N., Passariello, I., Sabbarese, C., Ricci, P., Gigli, S., Terrasi, F., 2013. Widespread fossil $\mathrm{CO}_{2}$ in the Ansanto Valley ( $\mathrm{AV}$ - Italy): dendrochronological, ${ }^{14} \mathrm{C}$ and ${ }^{13} \mathrm{C}$ analyses on tree rings. Radiocarbon 55 (2-3), 1114-1122.

Capretti, C., Macchioni, N., Pizzo, B., Galotta, G., Giachi, G., Giampaola, D., 2008. The characterization of waterlogged archaeological wood: the three roman ships found in Naples (Italy). Archaeometry 50 (5), 855-976.

Chiodini, G., Granieri, D., Avino, R., Caliro, S., Costa, A., Minopoli, C., 2010. Nonvolcanic $\mathrm{CO}_{2}$ earth degassing: case f Mefite d'Ansanto (southern Appennines), Italy. Geophys. Res. Lett. 37 (11), 1-4.

Colthup, N.B., Daly, L.H., Wiberley, S.E., 1990. Introduction to Infrared and Raman Spectroscopy. New York.

Corona, E., 2002. Xilologia e manufatti lignei storico-artistici. In: Borghini, G. Massafra, M.G. (Eds.), Legni da ebanista, pp. 15-17. Roma.

Čufar, K., Gričar, J., Zupančič, M., Koch, G., Schmitt, U., 2008. Anatomy, cell wall structure and topochemistry of water-logged archaeological wood aged 5,200 and 4,500 years. IAWA J. 29 (1), 55-68. 
Čufar, K., Merela, M., Eri, M., 2014. A Roman barge in the Ljubljanica river (Slovenia): wood identification, dendrochronological dating and wood preservation research. J. Archaeol. Sci. 44, 128-135.

Evans, P.A., Michell, A.J., Schmalzl, K.J., 1992. Studies on the degradation and protection of wood surface. Wood Sci. Technol. 26, 151-163.

Faix, O., 1986. Investigation of lignin polymer models (DPH's) by FTIR spectroscopy. Holzforschung 40 (5), 273-280.

Faix, O., 1991. Classification of lignins from different botanical origins by FT-IR spectroscopy. Holzforschung 45 (Suppl.), 21-27.

Fengel, D., 1991. Chemical studies on the wood of Quebracho colorado. (Schinopsis balansae Engl.). Part 2. Investigations of the lignin. Holforschung 45 (6) 395-401.

Gambino, N., 1991. La Mefite nella Valle d'Ansanto di Vincenzo Maria Santoli. Rilettura dopo duecento anni, vol. I/II. Rocca San Felice.

Grande, S., 2008. Il forziere di Mefite. In: Mele, A. (Ed.), Il culto della dea Mefite e la Valle d'Ansanto, pp. 273-288. Avellino.

Hodges, H., 2009. Artifacts. An Introduction to Early Materials and Technology. London.

Jacquiot, C., Trenard, Y., Dirol, D., 1973. Atlas d'anatomie des bois des angiospermes (essences feuillues). Paris.

Kajihara, J., Hattoris, T., Shirono, T., Shimada, M., 1993. Characterization of antiviral water-soluble lignin from Bagasse degraded by Lentinud edodes. Holzforschung 47 (6), 479-485.

Macchioni, N., Lazzeri, S., 2008. L'identificazione delle specie legnose e la loro caratterizzazione tecnologica. In: Fidanza, G.B., Macchini, N. (Eds.), Statue di legno. Caratteristiche tecnologiche e formali delle specie legnose, pp. 9-31. Roma.

Macchioni, N., Capretti, C., Sozzi, L., Pizzo, B., 2013. Grading the decay of waterlogged archaeological wood according to anatomical characterisation. The case of Fiavé site (N-E Italy). Int. Biodeterior. Biodegrad. 84, 54-64.

Manzi, R., 1997. Emanazioni gassose e sorgenti minerali della Valle d'Ansanto. Napoli.

McIntosh, J., 2009. Handbook of Life in Prehistoric Europe. Oxford.

Nardi Berti, R. 1994. La struttura anatomica del legno ed il riconoscimento de legnami italiani di più corrente impieg. Firenze.

Onorato, G.O., 1960. La ricerca archeologica in Irpinia. Avellino.

Ortolani, F., Pagliuca, S., 2008. Le manifestazioni idrotermali e il culto della de Mefite (provincia di Avellino): quadro geoambientale e rapporto uomoambiente durante le ultime migliaia di anni. In: Mele, A. (Ed.), Il culto della dea Mefite e la Valle d'Ansanto, pp. 23-56. Avellino.

Pandey, K.K., 1998. A study of chemical structure of soft and hardwood and wood polymers by FTIR spectroscopy. J. Appl. Sci. 71, 1969-1975.

Perini, R., 1988. La suppellettile lignea fra i resti degli antichi abitati di Fiavé e Lavagnone. In: Perini, R. (Ed.), Archeologia del legno. Documenti dell'età del bronzo dall'area sudalpina, pp. 65-94. Trento.
Pizzo, B., Giachi, G., Fiorentino, L., 2010. Evaluation of the applicability of conventional methods for the chemical characterization of waterlogged archaeological wood. Archaeometry 52 (4), 656-667.

Pizzo, B., Macchioni, N., Capretti, C., 2013a. Evaluating the state of preservation of waterlogged archaeological wood prior to conservation (chapter 7). In: Frediani, P., Frediani, M., Rosi, L. (Eds.), Cultural Heritage. Protection, Developments and International Perspectives. Focus on Civilizations and Cultures. Nova Science Publisher, New York, pp. 139-171.

Pizzo, B., Giachi, G., Fiorentino, L., 2013b. Reasoned use of chemical parameters for the diagnostic evaluation of the state of preservation of waterlogged archaeological wood. J. Archaeol. Sci. 40 (4), 1673-1680.

Pizzo, B., Pecoraro, E., Macchioni, N., 2013c. A new method to quantitatively evaluate the chemical composition of waterlogged wood by means of Attenuated Total Reflectance Fourier Transform Infrared (ATR-FT-IR) measurements carried out on wet material. Appl. Spectrosc. 67 (5), 553-562.

Rainini, I, 2003. Mephitis aedes o lucus consaeptus. Alcune osservazioni sul santuario della dea Mefite nella Valle d'Ansanto. In: Sanctuaires et sources dans l'antiquité, pp. 137-143. Napoli.

Rainini, I., 2008. L'area sacra della dea Mefite e l'insediamento vicano di Santa Felicita. Studi di topografia archeologica in Valle d'Ansanto. In: Mele, A. (Ed.), Il culto della dea Mefite e la Valle d'Ansanto, pp. 217-244. Avellino.

Relini, G., Faimali, M., 2003. Il Biofouling. In: Manuale di Metodologie di Campionamento e Studio del Benthos Marino Mediterraneo. Biol. Mar. Medit. 10, pp. 285-326.

Rivers, S., Umney, N., 2003. Conservation of Furniture. Oxford.

Rodrigues, J., Faix, O., Pereira, H., 1998. Determination of lignin content of Eucalyptus globulus wood using FTIR spectroscopy. Holzforschung 52 (1), 46-50.

Schultz, T.P., Glasser, W.G., 1986. Quantitative structural analysis of lignin by diffuse reflectance fourier transform spectrometry. Holzforschung 40 (Suppl.), $37-44$.

Schwanninger, M., Rodrigues, J.C., Pereira, H., Hinterstoisser, B., 2004. Effects of short time vibratory ball milling on the shape of FT-IR spectra of wood and cellulose. Vib. Spectrosc. 36, 23-40.

Schweingruber, F.H., 1990. Anatomie europaeischer Hoelzer. Stuttgart.

Silverstein, R., Webster, F.X., 1999. Identificazione spettroscopica di composti organici. Milano.

Sinno, R. 1969. I minerali della Valle di Ansanto: memorie geomineralogiche sulI'Italia centro-meridionale. In: Atti dell'Accademia di Scienze Fisiche e Matematiche, pp. 219-258, 7/3. Napoli.

Stotzer, M., Schweingruber, F.H., Šebek, M., 1976. Prähistorisches Holzhandwerk. In: Mitteilungsblatt der Schweizerischen Gesellschaft für Ur- und Frühgeschichte, pp. $13-23,27 / 8$.

Tagliamonte, G., 2005. I Sanniti:Caudini, Irpini, Pentri, Carricini, Frentani. Milano.

TAPPI Standard T211, 1993. Ash in Wood, Pulp and Paperboard: Combustion at $525^{\circ} \mathrm{C}$. New York. 